\title{
Pakārtojuma vārdu ka un kad lietojums mutvārdu tekstā
}

\section{The use of conjunctive words ka 'that' and kad 'when' in the spoken text}

\author{
Linda Lauze \\ Liepājas Universitāte, Humanitāro un mākslas zinātṇu fakultāte \\ Kūrmājas prospekts 13, Liepāja, LV-3405 \\ E-pasts:linda.lauze@liepu.lv
}

Gadu desmitiem valodas praksē ir aktuāls jautājums, ka bieži netiek nošḳirtas pakārtojuma vārdu $\mathrm{ka}$ un $\mathrm{kad}$ funkcijas un nozīme un apstākḷa vārds kad nepamatoti tiek lietots saikḷa $k a$ vietā. Pētījuma ieceri pārliecināties par konkrēto pakārtojuma vārdu lietojumu mutvārdu tekstā ir rosinājusi Kārḷa Mīlenbaha monogrāfijā „Teikums” izteiktā atziṇa par apstākḷa vārda kad izlaidumu salikta teikuma sākumā, kas raksturīgs tautas valodā.

Rakstā ir apkopots skatījums uz šo pakārtojuma vārdu lietojumu no valodas kultūras viedokḷa, to paplašinot ar teorētisku un praktisku analīzi salikta teikuma sintakses aspektā. Pētījuma praktiskā daḷa ir veikta, balstoties uz autentisku (dabiski veidotu) mutvārdu izteikumu analīzi.

Atslēgvārdi: mutvārdu teksts; valodas kultūra; sintakse; salikts pakārtots teikums; palīgteikums; saiklis ka; apstākḷa vārds kad.

Līdz šim publiskajā telpā par pakārtojuma vārdu ka un kad lietojumu mutvārdu tekstā ir dominējis skatījums no valodas kultūras viedokḷa. Gan atgādinājums, ka saiklis $k a$ ievada papildinātāja palīgteikumu, bet apstākḷa vārds kad - laika apstākḷa palīgteikumu, gan novērojums, ka daudzi valodas lietotāji rakstot prot izvēlēties palīgteikuma semantikai atbilstošo pakārtojuma vārdu, bet runājot diemžēl kḷūdās (sal. Miķelsone 1969; Freimane 1993, 254; Blinkena 2007, 200; Adamaite 2015).

Raksta mērķis ir analizēt pakārtojuma vārdu $k a$ un kad lietojumu mutvārdu tekstā ne tikai valodas kultūras aspektā, bet arī nozīmes un formas ziņā. Tiks pievērsta uzmanība faktam, ka šie pakārtojuma vārdi var ievadīt arī citu veidu palīgteikumus un ka apstākḷa vārds kad var ievadīt arī papildinātāja palīgteikumu.

Mutvārdu tekstā sastopamā neprecizitāte - apstākḷa vārda kad lietojums nevietā, proti, gadījumos, kad ir nepieciešams saiklis $k a,-$ nav jaunāko laiku parādība. Uz to jau ir norādījis Jānis Endzelīns latviešu valodas propedeitikas kursā: „,Ka vietā tautas valodā ḷoti bieži, tāpat kā leišu valodā, saka kad, piem., ,es zinu, kad viṇš nav vainīgs", bet rakstu valodā jāsaka ka - klasē un no katedras." (Grīsle 2010, 74) Par abu pakārtojuma vārdu jaukšanu vairākkārt ir rakstīts izdevumā „Latviešu valodas kultūras jautājumi” 20. gs. otrajā pusē. Aina Miḳelsone $(1969,70)$ ir uzsvērusi, ka katram no šiem vārdiem ir sava atšķirīga nozīme un uzdevums. Mērija SauleSleine (1982), norādīdama uz vārda kad izmantošanu saikḷa ka vietā kā vienu no 
valodas kḷūdām radioraidījumos, aicina vairāk ņemt vērā teikuma loǵiku. Marija Šūmane (1991) šo pašu kḷūdaino lietojumu ir konstatējusi televīzijā, kad ir runājuši žurnālisti un amatpersonas - cilvēki ar augstāko izglītību.

Mūsdienās turpinās tradīcija aplūkot pakārtojuma vārdu $k a$ un kad lietojuma kḷūmes populārzinātnisku rakstu krājumā „Valodas prakse: vērojumi un ieteikumi”. Elitas Stikutes un Baibas Zeiļakas (2017) rakstā „Valodas kultūras apguve vidusskolā" piemēri redzat, kad, liekas, kad iekḷauti citu valodas kultūras pārkāpumu vidū, raksturojot vienu no nevēlamo valodas variantu lietojuma noturības cēloṇiem. Skolā latviešu valodas stundās tiek veidoti valodas kultūras pamati, bet skolēnu kā nākamās paaudzes pārstāvju komunikatīvo kompetenci spēcīgi iespaido valodas vide ārpus stundām: „Diemžēl plašsaziņas līdzekḷi (laikraksti, dzeltenā prese, dažādas TV pārraides, šovi u. tml.) ne vienmēr piedāvā labus valodas paraugus. Globālajā tīmeklī, TV raidījumos, īpaši šovos, no sabiedrībā pazīstamu cilvēku mutes izskanējušie modes vārdi un parazītvārdi [..] ātri vien iesakn,ojas skolēnu valodā, un viņi šādu runāto valodu uztver par normu." (Stikute, Zeilıaka 2017, 155)

Raksta praktiskais materiāls (aptuveni 500 izteikumu, kas fiksēti televīzijā, radio un dažādās runas situācijās ikdienas saziṇā) liecina, ka vienā dạ̣ā gadījumu pakārtojuma vārds ir atbilstošs (1), bet otrā daḷā - apstākḷa vārds kad ir lietots saikḷa $k a$ vietā (2).

(1) a. Runas situācija uz ielas. Šoferis jautā pazīstamai garāmgājējai:

Neredzēji, $\boldsymbol{k a}$ es braucu? (LL 07.05.2012.) ${ }^{1}$

b. Runas situācija veikalā. Pircējs runā ar paz̄istamu pārdevēju par dejošanu deju kolektīvā. Pārdevēja aicina sākt apmeklēt deju nodarbības. Pircējs: Tu zini, $\boldsymbol{k a}$ man nepatīk. (LL 07.02.2019.)

c. Radioraidījuma vadītājs ir sagaidījis radioklausītājas zvanu no Vācijas: Tas brīdis ir pienācis, kad ir pienācis zvans no Vācijas. („LustīgsRadio” „Vakara programma” 04.04.2018.)

(2) a. Radioraidījuma vadītājs vēršas pie klausītājiem: Es ceru, kad noskan,ojums jums gan saulains, gan priecīgs. („Saldus radio” „Rīta programma" 31.08.2015.)

b. Radioraidījuma viesis stāsta par sporta pasākumu: Neskatoties uz to, kad sprinta disciplīna, es noskrēju arī maratonu. („Rietumu radio” „Centra auts” 06.02.2019.)

c. Runas situācija kafejnīcā. Kolēgé, sveikdama jubilāru, saka: Es gatavojos šim pasākumam ar noteikumiem, kad ir jālasa dzejolis Aivara dzimšanas dienā. (LL 24.02.2018.)

(2a) un (2b) gadījumā neatbilstošs pakārtojuma vārds izvēlēts papildinātāja palīgteikuma ievadīšanai, bet (2c) runas situācijā bija zināms tikai fakts par vienu jubilejas svinību scenārija daļu, nevis pulksteņa laiku, kad iecerētie dzejoḷu

Iekavās ikdienas saziṇā fiksētajiem mutvārdu teksta piemēriem norādīti pētījuma autores iniciāli, bet plašsaziņas līdzekḷos - televīzijas kanāls vai radiostacija un raidījuma nosaukums, kā arī datums. Visi mutvārdu teksti ir autentiski un nav rediğèti. 
priekšlasījumi tiktu īstenoti, tādējādi atbilstoši runātāju kopīgajām zināšanām un izteikuma saturam apzīmētāja palīgteikuma pakārtojumā labāk iederētos saiklis $k a$. Arī Jānis Kušķis grāmatā „Mūsu valoda” (2006, 81-82), kurā ir izteikti padomi valodas spodrināšanai, aicina nelietot nevietā vārdu $\mathrm{kad}$.

Ne reizi vien ir radies jautājums, kāpēc apstākḷa vārda kad lietojums saikḷa $k a$ vietā ir tik l,oti iesakņojies: varētu būt lietuviešu valodas ietekme, īpaši Lietuvas pierobežā, vai neapzināta runātāja vēlme ilgāk aizpildīt pauzi, kamēr viņš domā, ko teikt tālāk, pagarinot vārdu (ar līdzskani d), kā to dara, īsam vārdam pievienojot patskani, piem., un(a), ir(a) (plašāk par aizpildītajām pauzēm sk. Brēde 1999). Laikraksta intervijā Andrejam Veisbergam ir lūgts atbildēt uz jautājumu, vai pie kad lietojuma $k a$ vietā vajadzētu pierast, un kopumā viņa viedoklim var piekrist: „Ja šì novirze notiek lēnā, izsvērtā runā, man tas liekas dīvaini. Jo būtībā jau visi zina, ka jālieto „ka”. Ja „kad” iesprūk ātrā runā - un iesprūk gandrīz visiem -, es nebūtu tik kritisks. Neviens valodnieks nevar pamatoti izskaidrot, kāpēc tas notiek. Kārtējā valodas mīkla. Dzīva valoda nav reizrēksins. Rakstu valodā „kad” gan nevajadzētu piel̦aut." (Adamaite 2015)

Viens no abu vārdu jaukšanas cēloṇiem, iespējams, slēpjas to formas un lietojuma attīstības vēsturē, par ko ir sniegts pārskats grāmatas „Latviešu literārās valodas morfoloǵiskās sistēmas attīstība" 2. daḷā (Blinkena 2007, 196-202). Vēsturiski saiklim $k a$ ir piemitusi arī laika nozīme, kas minēta kā piektā (ME II, 128-129). Senākiem apstākḷa vārda kad lietojuma piemēriem saliktā teikumā ir norādīts variants ar saikli ka (Endzelīns 1951, 1039). Leksiskās nozīmes pārklāšanās, līdzịga cilme un funkcijas ir bijis pamats tam, ka ,latviešu valodā dažādos tās attīstības posmos un individuālo valodas lietotāju runā nereti netiek šķirts saikḷu ka un kad lietojums neitrālā saikḷa nozīmē” (Blinkena 2007, 199).

Sintakses aspektā ir svarīgi uzsvērt, ka pakārtojuma vārdi ka un kad mēdz ievadīt ne tikai papildinātāja palīgteikumu un apstākḷa vārds kad - laika apstākḷa palīgteikumu, kas, kā iepriekš rakstā minēts, ir vairāk akcentēts no valodas kultūras viedokḷa, bet arī citas semantikas palīgteikumu veidus (sk. tabulu).

Pārskatā par minēto pakārtojuma vārdu sintaktiskajām funkcijām ir redzams, ka tie abi var ievadīt teikuma priekšmeta (3), apzīmētāja (4) un papildinātāja palīgteikumu (5). Praktiskais materiāls apliecina, ka tas tiek īstenots arī mutvārdu tekstā.

(3) a. Sarunājas ǵimenes draugi. A stāsta, ka dēls akvaparkā bija pazaudējis aproci: Labi, ka atrada un nevajadzēja maksāt. (LL 25.06.2006.)

b. Sarunājas ğimenes locekḷi. Māte saka meitai: Es zinu, ko tas nozīmē, kad loti nāk miegs. (LL 27.05.2018.)

(4) a. Runas situācija skolā. Vecāku sapulcē tiek pārrunāta pusdienošanas kārtība starpbrīžos. Direktore jautā vecākiem: Jūsu priekšlikums ir tāds, ka mēs ieviešam kārtību, ka vienpadsmitos mazajiem ir priekšroka? (LL 22.12.2017.)

b. Radioraidījumā viešṇa dalās pārdomās par cel̦u uz panākumiem: Ir kaut kādi divi gadi, kad ir šaubīgi, nepārliecinoši. (,Radio SWH” „Ar dziesmu par dzīvi” 19.03.2016.) 


\begin{tabular}{|c|c|c|c|c|c|}
\hline $\begin{array}{c}\text { Palīgteikuma } \\
\text { veids }\end{array}$ & $\begin{array}{c}\text { MLLVG II } \\
\text { (1962) }\end{array}$ & $\begin{array}{c}\text { Latviešu } \\
\text { valodas } \\
\text { sintakse } \\
\text { (1989) }\end{array}$ & $\begin{array}{c}\text { Latviešu valodas } \\
\text { praktiskā } \\
\text { gramatika } \\
\text { (1991) }\end{array}$ & $\begin{array}{c}\text { Mūsdienu } \\
\text { latviešu literārāas } \\
\text { valodas sintakse } \\
\text { (2009) }\end{array}$ & $\begin{array}{c}\text { LVG } \\
(\mathbf{2 0 1 3 )}\end{array}$ \\
\hline $\begin{array}{l}\text { Teikuma } \\
\text { priekšmeta } \\
\text { palīgteikums }\end{array}$ & $\begin{array}{l}k a \\
k a d\end{array}$ & $\begin{array}{l}k a \\
k a d\end{array}$ & $\begin{array}{l}\text { ka } \\
\text { kad }\end{array}$ & $\begin{array}{l}k a \\
k a d\end{array}$ & $\begin{array}{l}k a \\
k a d\end{array}$ \\
\hline $\begin{array}{l}\text { Izteicēja } \\
\text { palīgteikums }\end{array}$ & $\begin{array}{c}k a \\
\text { (retāk citi } \\
\text { pakārtojuma } \\
\text { vārdi) } \\
\end{array}$ & $k a$ & $k a$ & $k a$ & $\begin{array}{l}k a \\
k a d\end{array}$ \\
\hline $\begin{array}{l}\text { Apzīmētāja } \\
\text { palīgteikums }\end{array}$ & $\begin{array}{c}k a \\
k a d\end{array}$ & $\begin{array}{l}k a \\
k a d\end{array}$ & $\begin{array}{l}k a \\
k a d\end{array}$ & $\begin{array}{c}k a \\
k a d\end{array}$ & $\begin{array}{l}k a \\
k a d\end{array}$ \\
\hline $\begin{array}{l}\text { Papildinātāja } \\
\text { palīgteikums }\end{array}$ & $\begin{array}{c}k a \\
k a d\end{array}$ & $\begin{array}{c}k a \\
k a d\end{array}$ & $\begin{array}{c}k a \\
k a d\end{array}$ & $\begin{array}{l}k a \\
k a d\end{array}$ & $\begin{array}{l}k a \\
k a d\end{array}$ \\
\hline $\begin{array}{l}\text { Laika apstākla } \\
\text { palīgteikums }\end{array}$ & kad & kad & $\mathrm{kad}$ & kad & kad \\
\hline $\begin{array}{l}\text { Veida apstākla } \\
\text { palīgteikums }\end{array}$ & $k a$ & $k a$ & $k a$ & $k a$ & $k a$ \\
\hline $\begin{array}{l}\text { Mēra apstākḷa } \\
\text { palīgteikums }\end{array}$ & - & $k a$ & $k a$ & $k a$ & $k a$ \\
\hline $\begin{array}{l}\text { Cēloṇa } \\
\text { apstākḷa } \\
\text { palīgteikums }\end{array}$ & $k a$ & $k a$ & $k a$ & $k a$ & $k a$ \\
\hline $\begin{array}{l}\text { Nolūka } \\
\text { apstākḷa } \\
\text { palīgteikums }\end{array}$ & $\begin{array}{c}k a \\
\text { Novec., sar. }\end{array}$ & $\begin{array}{c}k a \\
\text { Novec. }\end{array}$ & $\begin{array}{c}k a \\
\text { Novec. }\end{array}$ & - & - \\
\hline $\begin{array}{l}\text { Seku } \\
\text { palīgteikums }\end{array}$ & $k a$ & $k a$ & $k a$ & $k a$ & $k a$ \\
\hline $\begin{array}{l}\text { Nosacījuma } \\
\text { palīgteikums }\end{array}$ & $\begin{array}{l}\text { Retāk ka, } \\
\quad \text { kad }\end{array}$ & $\begin{array}{c}\text { Retumis } \\
\mathrm{ka}, \mathrm{kad}\end{array}$ & $\begin{array}{l}\text { Retāk ka, } \\
\quad \text { kad }\end{array}$ & - & - \\
\hline
\end{tabular}

Tabula. Pakārtojuma vārdu ka un kad sintaktiskās funkcijas

(4b) piemērā palīgteikums tuvāk paskaidro lietvārdu virsteikumā, ko tradicionāli uzskata par kritēriju apzīmētāja palīgteikuma noteikšanā. „Latviešu valodas gramatikā" par šāda pakārtojuma veida gadījumiem ir teikts, ka salikta pakārtota teikuma komponents ir klasificējams gan par laika apstākḷa, gan par apzīmētāja palīgteikumu, tādējādi atzīstot vienu no sintakses robežgadījumiem (Nītinga 2013, 874).

(5) a. Runas situācija dz̄̄voklī, kur apkure nav pietiekama. B jautā radiniecei, kura ir atnākusi ciemos: Nejūti, $\boldsymbol{k} \boldsymbol{a}$ ir auksts? (LL 07.01.2008.)

b. Radioraidījuma vadītāja atceras, ka reiz jau šie mūziḳi ir tikuši intervēti šajā raidījumā, tāpēc aicina vienu no viņiem: Nu pastāsti, kad tas bija un kā jums gāja. („Radio SWH” „Priekšnams” 25.03.2018.) 
Trijos avotos no izvēlētajām gramatikām un sintakses monogrāfijām (Ahero et al. 1962, 762; Ceplītis, Rozenbergs, Valdmanis 1989, 130; Ceplīte, Ceplītis 1991, 164) ir minēts, ka saiklis $k a$ un apstākḷa vārds kad reti ievada nosacījuma palīgteikumu. Fiksētajos runātās valodas piemēros diemžēl līdz šim nav izdevies konstatēt apskatāmo pakārtojuma vārdu lietojumu nosacījuma palīgteikumā.

Pievēršot īpašu uzmanību semantikai, kas ir saistīta ar pamatotu viena vai otra pakārtojuma vārda izmantojumu, parasti tiek salīdzināti līdzīgi teikumi, kas ir izdomāti un no teorijas viedokḷa atbilst rakstu valodai, kā, piem., Es zinu, ka tēvs atbrauks un Es zinu, kad têvs atbrauks (Miķelsone 1969, 70; Kalme 2001, 52). Tie uzskatāmi teorētiski ilustrē teikuma satura atšķirību starp objekta un laika nozīmi. Tas ir pirmkārt. Tomēr, pēc spontānās runas analīzes, šķiet, ka teikums ar laika nozīmi sarunvalodā būtu samākslots vai lietots ar ironiju, ja tēvs kavētos vai ja varētu domāt par īpašu gadījumu, kas rosinātu tēvu atnākt. Ja ievadītājvārds kad runā tiktu īpaši uzsvērts, atkarībā no konsituācijas ir iespējamas vēl citas izteikuma laika semantikas nianses. Parasti ikdienas saziņā piemin konkrētu pulksteņa laiku vai iesāk palīgteikumu ar vārdu cikos. Otrkārt, ir būtiski novērtēt virsteikumā izvēlētā darbības vārda rekciju, proti, vai atbilstoši savai nozīmei tas spēj piesaistīt papildinātāja palīgteikumu, kuru ievada saiklis $k a$ vai kurš var sākties ar vienu no abiem aplūkojamajiem pakārtojuma vārdiem, kas palīdz veidot atškiirīgu palīgteikuma saturu. Ne velti Inta Freimane (1993, 254) ir uzsvērusi, ka ,palīgteikuma ievadītājvārds var būt neprecīzs tāpēc, ka nav pareizi izvēlēts verbs un tā rekcija”. „Mūsdienu latviešu literārās valodas gramatikā” papildinātāja palīgteikuma raksturojumā ir skaidrots, ka ar apstākḷa vārdiem ievadīti palīgteikumi ,parasti ir atkarīgi no tiem pašiem verbiem virsteikumā, no kuriem atkarīgi ar saikḷiem ka un vai ievadītie palīgteikumi (resp. no verbiem, kas izsaka paziņojumu, vēstījumu, sajūtas, psihiskus procesus, jautājumu, kā arī mērḳtiecīgu darbību vai rīcību)" (Ahero et al. 1962, 685).

Ja papildinātāja palīgteikums ir pakārtots virsteikumā tādiem darbības vārdiem kā cerēt, likties, šķist, ir piel̦aujams tikai saikḷa $k a$ izmantojums palīgteikuma ievadītājvārda funkcijā. Daudzi citi verbi, piem., zināt, domāt, teikt, pateikt, l̦auj piesaistīt papildinātāja palīgteikumu gan ar vispārīgu objekta nozīmi, gan ar tādu objekta semantiku, kurā ir izteikta laika nianse. Mutvārdu tekstā daudzos gadījumos pakārtojuma vārda lietojums ir korekts (6), bet ir sastopamas arī neprecizitātes saikḷa $k a$ un apstākḷa vārda kad nošķīrumā, īpaši spontānā runā (7b).

(6) a. Runas situācija zobārstniecības kabinetā. Zobārsts saka pacientei: Es domāju, ka tur nekā nav. (LL 11.10.2011.)

b. Sarunājas kolēǵges. B šaubās, kurā laikā labāk zvanīt citai kolēgei darba jautājumā: Es domāju, kad viņai zvanīt. (LL 12.12.2018.)

(7) a. Runas situācija veikalā. Klients vēlas izmantot iespēju salabot preci tās garantijas laikā, bet nav pārliecināts, vai viss izdosies: Es gaidu vēl mènesi, un pēc 27 dienām man pateiks, $\boldsymbol{k a}$ tas nav iespējams. (LL 02.11.2015.)

b. Runas situācija augstskolā. Lekcijā studente brīvi stāsta par savu dzimto pusi: Ko es tā kā gribu pateikt, kad es dzīvoju lototi labā vietā. (LL 18.01.2019.) 
(7b) piemērā saliktā izteikuma palīgteikumā, pēc runas konteksta, ir domāts vispārīgs apgalvojums, kam būtu jāizsaka objekta nozīme, nevis laika nianse, kas raksturotu laika posmu, kad šajā vietā ir dzīvots. Tādējādi vārda kad izmantojums $k a$ vietā ir maldinošs. Iespējams, ka valodas praksē apskatāmā valodas kultūras jautājuma risināšanā varētu palīdzēt plašāks saraksts, kurā būtu noškirti virsteikumā lietojamie darbības vārdi palīgteikuma satura nianšu un ievadītājvārdu piesaistes zin̄ā.

Aina Miḳelsone $(1969,71-72)$ rakstā ,Saiklis $k a$ un apstākḷa vārds kad” ir secinājusi, ka „latviešu valodā apstākḷa vārdu kad nedrīkst lietot tais gadījumos, kad palīgteikums, kas jāpakārto saiklim $k a$, precizē vai paskaidro iepriekšējā teikuma dạ̣ā kādu vietniekvārda, apstākḷa vārda vai apstākḷa vārda un īpašības vārda formu". Šāds nosacījums vārda $k a$ izmantojumā tiek ievērots arī mutvārdu tekstā (8), bet gadās arī tā, ka runātājs ir sajaucis pakārtojuma vārdus (9). Piemēros minēto vārdšķiru vārdi virsteikumā ir izcelti.

(8) a. Radioraidījuma vadītājs jautā mūziķim telefonintervijā: Kā tu nonāci pie tā, $\boldsymbol{k} \boldsymbol{a}$ arī Edgars var uzrakstìt dziesmu? („LustīgsRadio” „Vakara programma” 12.03.2018.)

b. Runas situācija daudzdzīvokḷu mājas kāpṇutelpā. Kaimiṇiene saka kaimiņam: Re, kā jums labi, $\boldsymbol{k a}$ pastkastīte tik tuvu! (LL 18.12.2018.)

c. Televīzijas raidījuma vadītājs: Joprojām esmu lepns, $\boldsymbol{k a}$ strādāju ar jums vienā komandā. (LTV 1 „V.I.P.” 26.03.2018.)

(9) a. Runas situācija augstskolā. Lekcijā studente brīvi stāsta par savu pieredzi Dziesmu un deju svētkos lietainos laika apstākḷlos: Varēja rēķināties ar to, kad no arēnas izies slapjš ārā. (LL 18.01.2019.)

b. Sarunājas divi paziņas. C stāsta par savu dēlu, kurš prot angḷ un vācu valodu, bet nav mācījies krievu valodu: Viņš nezin it neko, un šobrīd situācija ir tāda, kad viňš faktiski darbu nevar dabūt tikai tāpēe, kad viņš nezin krievu valodu. (LL 15.11.2018.)

c. Radioraidījuma viesis saviḷnojoši stāsta par sava dēla hokejista karjeru: Es esmu l̦oti priecīgs, kad viņš spēlè hokeju, jo, paskatieties, hokejs tāds ìsts vīru, vīru, vīru tāds... (LR1 „Piespēle” 07.04.2018.)

Ir nepieciešams piebilst arī par pateicības frāžu sintaktisko izveidi. Ja virsteikuma pamatā ir izsauksmes vārds paldies, tam pakārtoto palīgteikumu ievada saiklis $k a(10)$. Izsauksmes vārdu gramatiskās savdabības dēl šādas teksta vienības tiek traktētas par salikta izteikuma analogiem (plašāk sk. Lauze 2011, 226-229).

(10) a. Radioraidījuma vadītājs saka viešņai: Paldies, $\boldsymbol{k} \boldsymbol{a}$ atradāt laiku atnākt un parunāt par šo izdevumu „Dainas”. (LR1 „Kultūras rondo” 13.07.2018.)

b. Televīzijas raidījuma vadītājs atvadās no viesiem: Paldies, $k \boldsymbol{a}$ bijāt šodien studijā, un tiekamies atkal šai raidījumā pēc nedēllas ,, Viens pret vienu” jau pēc vēlēšanām. (LTV 1 „,1 : 1”30.09.2014.)

Pakārtojuma vārdu $k a$ un $k a d$ lietojuma īpatnības nosaka arī salikta izteikuma uzbūves specifika mutvārdu tekstā. Ja informatīvi svarīgākais saliktā izteikuma 
saturs tēmas un rēmas aspektā ir ietverts palīgteikumā, tad tas atrodas izteikuma sākumā. Šādos gadījumos ir konstatējams gan saikḷa (11), gan bezsaikḷa (12) saistījums starp izteikuma daḷām (plašāk sk. Lauze 2013, 136).

(11) a. Runas situācija zobārstniecības kabinetā. Zobārsts vēršas pie pacientes, kurai būs atkārtoti jālabo zobs: Ka esmu pārsteigts, es neteiktu. (LL 31.01.2019.)

b. Runas situācija poliklīnikā. Uzgaidāmajā telpā par savu veselības stāvokli sarunājas divas pacientes. Viena no vin̄ām saka: Kad sanervozējas, tad ir cukurs augšā. (LL 22.11.2018.)

c. Runas situācija augstskolā. Studente stāsta kursabiedrenei, kāpēc vēl nav satikusi studiju darba vadītāju: Kad viņa varēja, tad es nevarēju. (LL 10.03.2018.)

(12) a. Runas situācija zobārstniecības kabinetā. Zobārsti D un E, no kuriem E ir jaunāks, spriež par implanta izmēru pacientam. D: Ar to pietiks, dzìves pieredze ir pierādījusi. (LL 13.02.2019.)

b. Runas situācija mājās, virtuvē. F paskaidro, kāpēc virtuve ir tik stipri izvēdināta: Tur bija dūmi, es domāju. (LL 16.11.2017.)

c. Sarunājas divas studentes, G spriež par dzīvokḷa saimnieci: Četrdesmit, man liekas, viņai ir. (LL 13.09.2018.)

(12c) gadījumā ir īpatnēja vārdu secība: salikts pakārtots izteikums sākas ar palīgteikumu, starp kura vārdiem ir virsteikums.

Īpašu interesi rada Kārḷa Mīlenbaha (2009, 267-268) monogrāfijas „Teikums” paragrāfā „Satura svars” analizētie piemēri, kuros laika apstākḷa palīgteikums bezsaikḷa saistījumā ir nostājies virsteikuma priekšā un kuros virsteikums sākas ar apstākḷa vārdu te. K. Mīlenbaha novērojums, ka tautas valodā nav dzirdēti tādi palīgteikumi, kas, novietoti salikta teikuma sākumā, sāktos ar apstākḷa vārdu kad, mūsdienu mutvārdu tekstā nav apstiprinājies.

Mutvārdu tekstā ir sastopami arī tādi pal̄̄gteikumi, kuri bezsaikḷa saistījumā ir novietoti aiz virsteikuma. Minētajos piemēros tie ir papildinātāja palīgteikumi, kuros ir izlaists saiklis $\mathrm{ka}$.

(13) a. Runas situācija autobusā. Šoferis stāsta savam pazinam, kā braucis ar lielu ātrumu, iztērējot vairāk degvielas: Kad uz 130, es pamanīju - zupu arī èd normāli. (LL 03.07.2014.)

b. Runas situācija daudzdz̄ivokḷu mājas pagalmā. Kaimiṇš saka kaimiņienei: Es saku rudens - nāk virsū. (LL 27.08.2012.)

c. Runas situācija daudzdzīvokḷu mājas kāpṇu telpā. Sarunājas divi kaimiņi F un G. F: Skatos, kaimiņš klibo. (LL 15.03.2017.)

\section{Secinājumi}

Mutvārdu teksta analīze liecina, ka daudzos gadījumos runātāji ir izvēlējušies palīgteikuma semantikai atbilstošu rakstā apskatīto pakārtojuma vārdu. Tomēr joprojām ir sastopams apstākḷa vārda $k a d$ izmantojums saikḷa $k a$ vietā, kas apliecina zināmu nevērību pret latviešu valodas gramatikas normām, īpaši spontānā runā. 
Iespējams, ka viens no pakārtojuma vārdu ka un kad jaukšanas iemesliem ir saistīts ar abu vārdu kopīgo cilmi un vēsturisko attīstību, turklāt to semantika un funkcijas tikušas nošķirtas relatīvi vēlu. Aina Blinkena (2007, 200) norāda, ka „20. gs. pirmajā pusē rakstu valodā un literārā runā kad un $k a$ lietojums diezgan stingri nostabilizējies un kad lietots tikai laika attieksmes raksturošanai”. Jāņem vērā arī fakts, ka abi vārdi var ievadīt viena tipa palīgteikumu - teikuma priekšmeta, apzīmētāja un papildinātāja pal̄̄gteikumu. Papildinātāja palīgteikuma gadījumā valodas lietotājam it seviški var rasties grūtības nošķirt palīgteikumus ar vispārīgu objekta nozīmi, ko ievada saiklis $k a$, no palīgteikuma, kurš objekta semantikā ietver laika nozīmes niansi un kura sākumā izmanto apstākḷa vārdu kad. Šì sintakses un valodas kultūras jautājuma kompleksā risināšanā varētu palīdzēt plašāks saraksts, kurā būtu nošķirti virsteikumā lietojamie darbības vārdi palīgteikuma satura nianšu un ievadītājvārdu piesaistes ziņā.

Gatavojot publisku runu, pirmskomunikācijas fāzē teksta autoram parasti ir iespējams iepriekš pārdomāt vārdu izvēli vai pat izveidot daļēju vai pilnīgu rakstveida uzmetumu. Tādējādi varētu noderēt rakstā apkopotās atziṇas. Spontānā runā korektu pakārtojuma vārdu $k a$ un kad izmantojumu varētu nodrošināt automātiska gramatisko normu ievērošana, kas raksturīga izglītotam runātājam ar bagātu vārdu krājumu. Ir vērts paturēt prātā, ka nezināšanas gadījumā runāšanas brīdī ir iespējams veidot bezsaikḷa palīgteikumu, lai izvairītos no potenciālās kḷūmes. Interesanti, ka pētījumā nav konstatēts saikḷa $k a$ lietojums apstākḷa vārda kad vietā.

\section{Saīsinājumi}

LVG Latviešu valodas gramatika. 2013. Nītiņa, Daina, Grigorjevs, Juris (red.). Rīga: LU Latviešu valodas institūts.

ME II Mīlenbahs, Kārlis. 1923. Latviešu valodas vārdnīca. Redig̣ējis, papildinājis, turpinājis J. Endzelīns. 2. Rīga: Izglītības ministrija.

MLLVG II Ahero, Antonija et al. 1962. Mūsdienu latviešu literārās valodas gramatika. II. Sintakse. Rīga: LPSR ZA izdevniecība.

\section{Literatūra}

1. Adamaite, Undīne. 2015. Valodnieks Andrejs Veisbergs: Mums ir loti laba gramatika. Diena: Kultūras Diena. 15.02.2015. Pieejams: https://www. diena.1v/raksts/kd/intervijas/valodnieks-andrejs-veisbergs-mums-ir-loti-labagramatika-14087334.

2. Ahero, Antonija et al. 1962. Mūsdienu latviešu literārās valodas gramatika. II. Sintakse. Rīga: LPSR ZA izdevniecība.

3. Beitiņa, Maigone. 2009. Mūsdienu latviešu literārās valodas sintakse. Liepāja: LiePA.

4. Blinkena, Aina. 2007. Konjunkcija (saiklis). Latviešu literārās valodas morfologiskās sistēmas attīstība. 2. Rīga: LU Latviešu valodas institūts, 100-309.

5. Brēde, Maija. 1999. Aizpildītās pauzes publiskās runas stilā. Linguistica Lettica. 5. Rīga: Latviešu valodas institūts, 154-161.

6. Ceplīte, Brigita, Ceplīitis, Laimdots. 1991. Latviešu valodas praktiskā gramatika. Rīga: Zvaigzne. 
7. Ceplītis, Laimdots, Rozenbergs, Jānis, Valdmanis, Jānis. 1989. Latviešu valodas sintakse. Rīga: Zvaigzne.

8. Endzelīns, Jānis. 1951. Latviešu valodas gramatika. Rīga: Latvijas Valsts izdevniecība.

9. Freimane, Inta. 1993. Valodas kultūra teorētiskā skatījumāa. Rīga: Zvaigzne.

10. Grīsle, Rasma. 2010. Jāṇa Endzelīna latviešu valodas propaideutikas lekciju kurss. Rīga: Ingmara Zemzaŗa apgāds, Rīgas Latviešu biedrības valodas attīstības kopa.

11. Kalme, Vilma. 2001. Nelokāmās vārdšķiras latviešu literārajā valodā. Liepāja: LiePA.

12. Kušķis, Jānis. 2006. Mūsu valoda. Padomi valodas spodrināšanai. Rīga: Antava, Rīgas Latviešu biedrības valodas attīstības kopa.

13. Lauze, Linda. 2011. Pateicības frāzes mutvārdu saziṇā. Vārds un tā pētǐšanas aspekti. 15(2). Liepāja: LiePA, 223-231.

14. Lauze, Linda. 2013. Salikts teikums un tā realizācija mutvārdu tekstā. Vārds un tā pētī̌sanas aspekti. 17(1). Liepāja: LiePA, 134-142.

15. Miḳelsone, Aina. 1969. Saiklis ka un apstākḷa vārds kad. Latviešu valodas kultūras jautājumi. 5. Rīga: Liesma, 70-72.

16. Mīlenbahs, Kārlis. 2009. Teikums. Darbu izlase. 1. Druviete, Ina (sast.), Lagzdina, Sarmīte (zin. red.). Rīga: LU Latviešu valodas institūts, 221-296. [Pirmizdevums: Rīga: Pūcīšu G̣ederta apgādībā, 1898.]

17. Nītiņa, Daina. 2013. Salikts pakārtots teikums. Latviešu valodas gramatika. Nīina, Daina, Grigorjevs, Juris (red.). Rīga: LU Latviešu valodas institūts, 843-875.

18. Saule-Sleine, Mērija. 1982. Valodas kḷūdas radioraidījumos. Latviešu valodas kultūras jautājumi. 18. Rīga: Avots, 135-137.

19. Stikute, Elita, Zeil̦aka, Baiba. 2017. Valodas kultūras apguve vidusskolā. Valodas prakse: vērojumi un ieteikumi. 12. Šaudiņa, Vilma (atb. red.). Rīga: Latviešu valodas aǵentūra, 153-166.

20. Šūmane, Marija. 1991. Kā runājam latviski. Latviešu valodas kultūras jautājumi. 26. Rīga: Avots, 202-204.

\section{Summary}

The present article deals with the use of conjunctive words $k a$ 'that' and kad 'when' in the spoken text. Up to now there are some actual issues related to choosing the correct conjunctive word. It is a widespread mistake to use an adverb kad instead conjunction ka when implementing the structure of the complex sentence especially in spoken text. The fixed material was recorded from television and radio broadcasts and different speech situations in everyday communication.

The research has been focused on semantics and types of subordinate clauses from the point of view of syntax of the Latvian language. It is necessary to pay more attention to those types of complex sentence to use both conjunctive words (see Table 1). Object clause belongs to above-mentioned types. It is stated that in definite cases only the use of the conjunction $k a$ is highly recommended. It is connected not only with semantics of the subordinate clause but also with valency of the verb being in the center of the main clause.

Keywords: language planning; syntax; spoken text; conjunction $\mathrm{ka}$; adverbial modifier $\mathrm{kad}$. 